\title{
INTRAVENOUS REGIONAL ANAESTHESIA *
}

\author{
O S DAwKrins, MD, M SC, E S. RUSSELL, B A, MD, \\ A $\mathbb{K}$ ADAMS, M B , CH B, F F A R S $\mathbb{R} \mathbb{L}$ HOOPER, B SC (PHM), MD, \\ O A Odiakosa, M B, CH B, ANd S A Fleming, B A, M D, F F A R CS
}

THE INTRAVENous ADMINISTRation of local anaesthetic drugs in clinical medicine was initiated by Bier in 1908 Holmes, ${ }^{1}$ in February 1963, reported thirty cases for which he employed a modification of Bier's "venous anaesthesia" The technique has been readily adopted by the Anaesthetic team in the new Teaching Hospital in Lagos, where many patents appear lor emergency treatment of lesions of the extremities The 514 patients in this serres were anaesthetized during the eight-month period from April to December, 1963 They were unpremedicated and unprepared in that food had possibly been eaten within a short tume of anival

\section{Methods}

A sphygmomanometer cuff was applied to the affected extremity of the recumbent patient and the blood pressure was measured prior to dramage of the extremity and again one minute after final release of the tourniquet For hand infections the anaesthetist had the choice of applying the cuff above or below the elbow

A 20-c c syringe loaded with lignocaine was attached to a needle (SWG 22), which was introduced into a surtable vein distal to the cuff After elevating the extremity for one minute to allow venous drainage, the cuff was inflated above the systolic pressure, the extremity was returned to the horizontal position, and the solution of lignocaine was administered in a single injection The surgeon then prepared the extremity and performed the necessary operation, the dressing was applied, and the sphygmomanometer cuff was deflated

Holmes and Bier preferred the Esmarch bandage for the exsangumation of the extremity, but in the few cases in which it was used here, it afforded no paiticular advantage over the method of gravitational dramage

The concentration of lignocaine used varied between 05 and 20 per cent, while the injected volume ranged from 10 to $40 \mathrm{cc}$ for the first 150 patients Then it was decided that a 1 per cent lignocame solution was the most satisfactory and that $20 \mathrm{cc}$ would be adequate for an adult The majority of the patients were 20 to 60 years of age and required this chosen lignocame dosage of $200 \mathrm{mg}$ Children up to 15 years of age and patients over 60 years were given smaller doses as determined by each investigator for the individual patient

The surgical procedure was begun two to five munutes after the injection of the lignocaine, and was completed usually in less than five minutes, so that the

From the Department of Anaesthesia, University of Lagos Medical School and Lagos Univeısity Teaching Hospital, Lagos, Nigena 
estimated period of analgesia was ten minutes. The range of surgical penod was from 2 to 70 minutes For two orthopaedic procedures on bone and tendon the patients comfortably withstood the surgical onslaught for 70 minutes In a limited number of cases the duration of analgesia after removal of the tourniquet was determined by testing response to a pin-prick A painful stımulus was experienced by many patients withm one minute of re-establishing the circulation to the limb, following a very short procedure, and in another four minutes the limb was completely sensitive to pin-prick The longer the period of inflation of the cuff, the longer was the penod of analgesia after it was deflated

The majonty of the patients (465) had operations performed on the upper extremity and only 39 on the lower (It was often impossible to find a vein in the leg ) Most of the patients had infections necessitating wide-spread incision and drainage, but lacerations, ganglia, and fractures were also treated

\section{Results}

The largest dosage of $800 \mathrm{mg}$ was injected with no complications into the upper limbs of an 18-year-old boy with bilateral severe wrist lacerations A 21-year-old man undergoing a closed reduction of his right forearm, who also received $800 \mathrm{mg}$, developed generalızed twitchings, which soon subsided without treatment

The oldest patient, an 86-year-old woman, received $200 \mathrm{mg}$ of lignocaine for incision of her index finger The surgical procedure lasted six minutes, with an estimated period of analgesia of ten minutes, and there was no untoward effect The youngest patient, a $4 \frac{1}{2}$-year-old boy, who received $60 \mathrm{mg}$ of lignocaine for needling of subungual haematomata and incision of a boil on the forearm, cried at the beginning of the surgical procedure.

For the 24 patients 5 to 10 years of age, the usual dosage was $100 \mathrm{mg}$ of lignocaine Some neurological complications were observed in this group of patents The first was in a 7-year-old boy who received $200 \mathrm{mg}$ for incision of a finger After the operation, which lasted five minutes, the child had nystagmus and facial twitching on release of the tourniquet The second was in a 7-yearold girl who received $100 \mathrm{mg}$ of lignocaine for drainage of a hand infection She developed mild convulsions on release of the tourniquet after an operation lasting three minutes Neurological complications were also exhibited by two 18-year-old boys who received 200 and $300 \mathrm{mg}$ of lignocaine respectively, the first man1fested nystagmus, ataxia, and complained of dizziness, while the second had a major seizure, which was controlled by the use of thiopental In the same age group four patients receiving $400 \mathrm{mg}$ of lignocaine exhibited neurological or cardiovascular complications In all, nine patients had neurological complications ranging from mild headache to frank, generalized convulsions

Blood pressure changes determined within one minute of removing the tourn1quet were equivocal There were two cases with orthostatic hypotension and syncope on rising which reverted in the supine position

Each investigator recorded the evaluation of the analgesic response over the complete dosage range The anaesthesia was graded as good, moderate, fair, or 
poor, Good results were obtained for 95 per cent of the cases, while the analgesia was definitely poor for fewer than 15 per cent O1 the 373 patients who received the chosen standard dosage of $200 \mathrm{mg}$ of lignocame in $20 \mathrm{c} \mathrm{c}, 92$ per cent showed good results and fewer than 1 per cent poor results There was some difficulty in assessing the degree of analgesia in the majority of patients because of the language barmer

One of the anaesthetists, who was given this form of anaesthesia three tumes for incision of boils on his arm, considered it completely satusfactory During the injection of the $20 \mathrm{cc}$ of 1 per cent lignocaine there was a slight feeling of fulness of his hand but no discomfort (some patients made grimaces suggesting suffering, and some complained of a burning sensation) $\mathbb{H}_{11}$ hand was numb to pin-prick two minutes after an injection in the forearm, however, after injection into the antecubital fossa, the whole hand did not become completely anaesthetzed There was some loss of muscle power Both pin-prick sensation and power returned completely in five minutes on one occasion he experienced tinnitus and mild disorientation on release of the tourniquet after a very short procedure

\section{Discussion}

An intravenous regional anaesthetic technique has been presented in this paper as being relatively harmless and certainly effective in surgery on the extremities The mechanism of action of lignocaine when employed intravenously for regional anaesthesia in this manner needs to be elucidated subsequent neurophysiological investigations should help to solve this mystery

Neuiological complications were manifested by fewer than 2 per cent of the patients in this senes These were mostly of the minor variety, consisting of disorientation, extreme talkativeness, disequilibrium on standing, and tunnitus Fewer than 1 per cent convulsed and in only one instance was it necessary to administer thiopental De Clive-Lowe et al ${ }^{2}$ reported three cases of convulsion in 900 intravenous administrations at a dosage rate of $075 \mathrm{mg}$ of lignocame per hour for operative procedures lasting approximately one hour Subsequently, they stated in a report of 400 administrations of intravenous lignocanne for postoperathe analgesia that no convulsions occurred if the maximum dosage of $500 \mathrm{mg}$ in the first hour was not exceeded ${ }^{3}$ In the present series, early removal of the tourniquet after injection may have released toxic amounts of lignocaine into the crrculation Cardiovascular complications occurred in fewer than 05 per cent of the patients

The method permitted expeditious treatment of out-patients with no prolonged recovery penod necessitating extra space and attendants An advantage over brachial block anaesthesia was the immediate return of motor function

\section{SUMMary}

Regional anasthesia for surgery of the extremities was produced by intravenous injection of lignocame into the $1 \mathrm{mb}$ A sphygmomanometer cuff was placed on the $1 \mathrm{mb}$ of the recumbent patient and inflated to occlude the venous drainage 
Venipuncture was then done with a small needle (22 SWG) attached to a syringe containing lignocame solution. The cuff was then deflated, the limb was elevated for one-half to one minute to permit venous drainage, the cuff was then inflated above the systolic pressure, the arm was lowered, and the lignocame solution was injected Intravenous lignocaine solution was given in this manner to 514 patients between the ages of $4 \frac{1}{2}$ and 86 years, the dose varying from 60 $\mathrm{mg}$ to $800 \mathrm{mg}$ Of these patients, 373 received $200 \mathrm{mg}$ of lignocaine in $20 \mathrm{cc}$, which is now considered an adequate standard dose in the adult Over the whole dosage range 95 per cent had good analgesıa, and 15 per cent were classified as poor Of the group receiving $20 \mathrm{c} \mathrm{c}$ of 1 per cent lignocaine, 92 per cent had good analgesia, while fewer than 1 per cent had poor analgesia, there was a reduction in neurological and cardiovascular complications on release of the tourniquet for the patients who recerved the smaller quantities Surgical anaesthesia was good for at least 60 minutes This method of anaesthesia of the extremities is recommended for the efficient operation of a casualty theatre service

\section{RESUME}

Pour la chirurgie des extıémités, on a faıt une anesthésıe régınale en injectant de la lignocame dans les veines d'un membre On a placé à la racine du membre le manchon d'un sphygmomanomètre et on l'a gonflé pour empêcher le retour verneux On a alors ponctionné une veine à l'arde d'une argulle 22 reliée à une sernngue contenant la solution de lignocarne On a alors dégonflé le manchon, et on a élevé le membre durant 30 à 60 secondes pour permettre le dranage veineux, puis, on a gonflé le manchon à une pression supérieure à la pression systolique, on a ieplacé le membre en position horizontale et on a injecté la solutoon de lignocane 514 malades, dont l'âge variant de $4 \frac{1}{2}$ ans à 86 ans, ont reçu une solution de lignocaine d'après cette technique La dose a varié de 60 à 800 mg 373 de ces malades ont reçu $200 \mathrm{mg}$ de lignocaine dans $20 \mathrm{cc}$, ce qui est consıdéré comme une dose suffisante chez l'adulte Dans l'ensemble, 95 pour cent ont bénéficité d'une bonne analgésıe, et 15 pour cent d'une analgésı médıcre Parmi ceux qui ont reçu $20 \mathrm{cc}$ de lignocaine à 1 pour cent, 92 pour cent ont bénéficié d'une bonne analgésıe et moins de 1 pour cent, d'une analgésıe médıocre, par alleurs, les complications neunologiques et cardio-vascularres ont été moins fréquentes lorsqu'on a enlevé le garrot, pas rapport à ceux qui avarent reçu de plus fortes doses L'anesthésie chururgicale a duré au moins une heure Cette technique d'anesthésie des extrémités est partıculièrement efficace si l'on doit intervenir chez les accidentés

\section{REFERENCES}

1 Holmes, C M K Regronal Analgesia Lancet a 245 (1963)

2 DE Clive-Lowe, S G, Spencer Gray, $P$ W, \& Norta, I Succinyldicholue and Lignocame by Contrauous Intravenous Drip Anaesthesia 996 (1954)

3 De Clive-Lowe, $\$$ G, Drsmond, J, \& North, I Intravenous Lignocane Anaesthesia Anaesthes1a $13 \quad 138$ (1958) 